\title{
Arsenic and lead (beudantite) contamination of agricultural rice soils in the Guandu Plain of northern Taiwan
}

\author{
Kai Ying Chiang a, Kuo Chuan Lin ${ }^{\mathrm{b}}$, Sheng Chi Lin ${ }^{\mathrm{c}}$, Tsun-Kuo Chang ${ }^{\mathrm{c}}$, Ming Kuang Wang ${ }^{\mathrm{a}, *}$ \\ a Department of Agricultural Chemistry, National Taiwan University, No. 1, Sec. 4, Roosevelt Rd., Taipei 10617, Taiwan \\ ${ }^{\mathrm{b}}$ Division of Silviculture, Taiwan Forestry Research Institute, COA, Taipei 10017, Taiwan \\ ${ }^{c}$ Department of Bioenvironmental Systems Engineering, National Taiwan University, Taipei 10617, Taiwan
}

\section{A R T I C L E I N F O}

\section{Article history:}

Received 3 December 2009

Received in revised form 27 May 2010

Accepted 27 May 2010

Available online 2 June 2010

\section{Keywords:}

Agricultural paddy soils

Beudantite

Hot springs

Sequential extraction

\begin{abstract}
A B S T R A C T
This study investigates the species of $\mathrm{As}$ and $\mathrm{Pb}$ (beudantite) residues present in the seriously contaminated agricultural rice soils of the Guandu Plain. Two pedons in the Guandu Plain agricultural soils, each pedon separated into five horizons (each of $20 \mathrm{~cm}$ ) were collected for this study. Soil samples were packed into a column for leaching with simulated acid rains. Soil pH ranged from 5.1 to 7.1 with high base saturation. Soils can be classified as clay loam, mixed, thermic, Typic or Umbric Albaqualfs. The XRD analysis indicated the beudantite particles are present in clay fractions, showing high concentrations of As and $\mathrm{Pb}$. This is because of 50-100 years ago irrigation water was introduced from Huang Gang Creek of hot springs containing high concentrations of $\mathrm{As}$ and $\mathrm{Pb}$. Only low concentrations of $\mathrm{As}$ and $\mathrm{Pb}$ can be leached out with simulated acid rains (i.e., pHs 2 and 4), even through 40 pore volumes of leaching experiments. The sequential extraction experiments resulted in the high portions of $\mathrm{As}$ and $\mathrm{Pb}$ remaining in the amorphous, $\mathrm{Fe}$ and $\mathrm{Al}$ oxyhydroxides and residual fractions. Thus, the remediation of $\mathrm{As}$ and $\mathrm{Pb}$ in this agricultural rice paddy soils merits further study.
\end{abstract}

(c) 2010 Elsevier B.V. All rights reserved.

\section{Introduction}

Taiwan was colonized by the Japanese Government from 1895 to 1945 . At that time, farmers occasionally irrigated the Guandu agricultural rice soil during the drought seasons with water from Huang Gang Creek, unaware of the presence of arsenic (As), lead $(\mathrm{Pb})$ and sulfate $\left(\mathrm{SO}_{4}\right)$ contaminants in the spring waters (personal communications with older local farmers). The irrigation water in the Huang Gang Creek originated from the Beitou Thermal Valley (i.e., outcrop size about 0.35 ha) of hot spring water (Fig. 1). From a previous soil survey, the $\mathrm{As}$ and $\mathrm{Pb}$ contaminated soils in the Guandu rice soils cover about 842 ha, and the serious As (As concentrations higher than $60 \mathrm{mg} \mathrm{kg}^{-1}$ ) contamination of rice soils in the Guandu Plain cover about 128 ha $[1,2]$.

\section{Geological settings}

\subsection{Pleistocene volcanic rocks in northern Taiwan}

Large scale andesitic volcanic eruptions took place in northern Taiwan and in some northeastern offshore islands during the

\footnotetext{
* Corresponding author. Tel.: +8862 3366 4808/2118; fax: +88622366 0751.

E-mail addresses: mkwang@ntu.edu.tw, mkwang@ccms.ntu.edu.tw (M.K. Wang).
}

Pleistocene. Both andesitic lavas and andesitic pyroclastics are represented. Two important Pleistocene volcano groups were formed, the Tatun Volcano Group and the Chilung Volcano Group [3]. No volcano is known to be active in Taiwan in the historical record but these volcanoes may not be entirely extinct since geothermal evidence is still extensive in this area.

The Tatun Volcano Group comprises a series of andesitic volcanoes in the northernmost part of Taiwan, the nearest being $15 \mathrm{~km}$ northeastern of Taipei City (Fig. 1A). Hot springs, fumaroles, and solfataras are found at many places in this volcano group, mostly on the southeast side of the Chinshan longitudinal geological fault. There are clear surface manifestations of geothermal steam in the volcanic area, and exploration for geothermal resources has been going on for many years [3].

\subsection{Environmental information nearby Guandu Plain}

The outcrop of hot springs of the Chinshan geological fault (Tatun Vocanoes) is located at Beitou Thermal Valley which is on the eastern part of the Guandu Plain (distance about $5 \mathrm{~km}$ ) (Fig. 1B). In the water from these hot springs the $\mathrm{pH}$ ranges from 1.57 to 1.75 , the temperature from 60.3 to $64.5^{\circ} \mathrm{C}$, arsenic (As), sulfate $\left(\mathrm{SO}_{4}\right)$ and lead $(\mathrm{Pb})$ concentrations of the hot springs range from 3.71 to 5.95 (As) and 1813 to $4293 \mathrm{mg} \mathrm{L}^{-1}\left(\mathrm{SO}_{4}\right)$ and 302 to $414 \mu \mathrm{g} \mathrm{L}^{-1}(\mathrm{~Pb})$, respectively $[4,5]$. The $\mathrm{pH}$, temperature, and concentrations of $\mathrm{Pb}$ and As in thermal spring waters, however, are dependent on the 


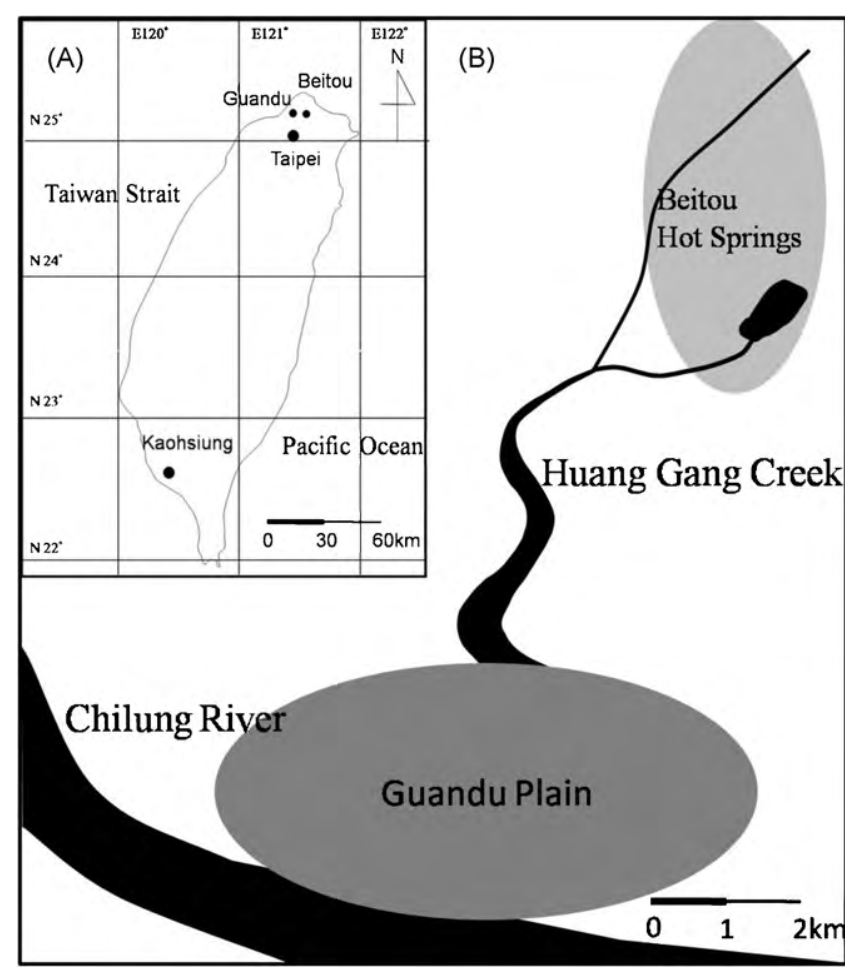

Fig. 1. Location of (A) Beitou and Guandu, and (B) Beitou hot springs, Huang Gang Creek and the Guandu Plain.

precipitation level and sampling season. It was lucky that no black foot diseases occurred in this region because of the stink smelling of hot spring waters.

Hot springs along the Huang Gang Creek flow into the Chilung River. The Chilung River is one of the major watersheds in the northern part of Taiwan and flows around the south-western boundary of the Guandu Plain from east to west until it merges with the Danshui River watersheds and the Taiwan Strait Estuary.

Due to long-term water flows from Beitou hot springs (i.e., from several tens of thousands to millions of years), thus we can find substantial amounts of beudantite $\left[\mathrm{PbFe}_{3}\left(\mathrm{AsO}_{4}\right)\left(\mathrm{SO}_{4}\right)(\mathrm{OH})_{6}\right]$ deposits, crystals or rocks present on the banks of the Huang Gang Creek. In addition, hokutolite $\left[(\mathrm{Ba}, \mathrm{Pb}) \mathrm{SO}_{4}\right]$ and barium sulfate (barite) with radium $(\mathrm{Ra})$ radioisotope are also present in the center part of the Huang Gang Creek for unknown reasons [6]. There has been misinterpretation these deposits as jarosite $\left[\mathrm{KFe}_{3}\left(\mathrm{SO}_{4}\right)_{2}(\mathrm{OH})_{6}\right]$ [7]. Since the X-ray diffraction (XRD) pattern of jarosite (JCPDS 22-827) is similar to that of beudantite (JCPDS 19-689).

The climate in this region is humid, with mean annual air temperature of $25.7^{\circ} \mathrm{C}$ and mean annual precipitation of $2471 \mathrm{~mm}$. The ground water table is always high during the typhoon and monsoon seasons [8]. This study investigates the species of As and $\mathrm{Pb}$ (beudantite) residues presented in seriously contaminated agricultural rice soils of the Guandu Plain.

\section{Experimental}

\subsection{Soil samplings}

Two pedons \#1 and \#2 were located at $25^{\circ} 7^{\prime} 40.87^{\prime \prime} \mathrm{N}$ and $121^{\circ} 29^{\prime} 47.37^{\prime \prime} \mathrm{E}$ (pedon 1 ), and $25^{\circ} 7^{\prime} 35.26^{\prime \prime} \mathrm{N}$ and $121^{\circ} 29^{\prime} 46.19^{\prime \prime} \mathrm{E}$ (pedon 2), in the subtropical Guandu Plain (Fig. 1). Two individual soil profiles with $\mathrm{As}$ and $\mathrm{Pb}$ contamination were collected for this study. These two soil profiles have five horizons in each depth ( $20 \mathrm{~cm}$ interval) which were analyzed to determine chemical and mineralogical differences with soil depth [9].

\subsection{Laboratory analyses}

Soil samples were air-dried, and crushed to pass through a 2mm sieve. Organic matter was removed by $30 \% \mathrm{H}_{2} \mathrm{O}_{2}$ and heating on a hot plate. For improved identification of soil clay minerals by $\mathrm{X}$-ray diffraction (XRD) analysis and identification of the $\mathrm{As}$ and $\mathrm{Pb}$ species in soil clays, the soil samples were treated and not treated with dithionite-citrate-bicarbonate (DCB) and heated at $80^{\circ} \mathrm{C}$ to remove and not remove Fe-oxides, respectively [10]. The silt was separated from the sand by wet-sieving (53 $\mu \mathrm{m}$ sieve) [11]. The clay fractions were dialyzed again with distilled water and then freeze-dried.

Soil $\mathrm{pH}$ was determined for $1: 1$ soil to water suspensions using a $\mathrm{pH}$ meter. For cation-exchange capacity (CEC) determination, $10 \mathrm{~g}$ of air-dried soil samples were equilibrated with $90 \mathrm{~mL} 1 \mathrm{M} \mathrm{NH}_{4}$ acetate ( $\mathrm{pH} 7.0$ ) solution and washed with $10 \% \mathrm{NaCl}$ solution. The $\mathrm{NH}_{4}$ concentrations were determined by the Kjeldahl method [12]. Soil bulk and particle densities were determined using the core and density bottle methods [13].

The deferrated soil clays were saturated with $\mathrm{Mg}$ and $\mathrm{K}$, and mounted as slurries on glass slides for XRD analysis [14]. The $\mathrm{Mg}$-saturated clays were examined at $25^{\circ} \mathrm{C}$ before or after glycerol solvation. The K-saturated clays were examined at $25^{\circ} \mathrm{C}$ and after heating at $105,250,350,450$ and $550^{\circ} \mathrm{C}$ for $2 \mathrm{~h}$. The oriented clay mineral aggregates were examined with X-ray diffractometer (Rigaku Geigerflex) with $\mathrm{Cu} \mathrm{K} \alpha$ radiation at $35 \mathrm{kV}$ and $18 \mathrm{~mA}$, recorded in the range of $3-50^{\circ} 2 \theta$. Powder XRD patterns of the sand, silt and clay fractions were recorded in the range of $3-80^{\circ} 2 \theta$ with a scan rate of $2^{\circ} 2 \theta \mathrm{min}^{-1}$. The soil clay samples without DCB treatments and bulk beudantite samples collected from the bank of Huang Gang Creek were also subjected to powder XRD analysis. The CEC values of $\mathrm{K} / \mathrm{NH}_{4}$ and $\mathrm{Ca} / \mathrm{Mg}$ exchange were used to determine the quantity of vermiculite $[15,16]$. The quantity of illite was estimated from the $\mathrm{K}_{2} \mathrm{O}$ content. In clay samples, kaolinite was estimated by the XRD peak intensity at $7.1 \AA$ [17]. Then $0.25 \mathrm{mg}$ of bulk and clay fraction samples was digested with $5 \mathrm{~mL}$ aqua regia solutions, and $\mathrm{As}$ and $\mathrm{Pb}$ concentrations were determined by Inductively Coupled Plasma-Atomic Emission Spectrometry (ICPAES, Perkin-Elmer, Model Optima 2000 DV).

\subsection{Scanning electron microscopy (SEM) and energy dispersive spectrometer (EDS)}

A scanning electron microscope was used to examine clay fractions without deferration of freeze-dried samples. Samples were fixed onto aluminum stubs with double-stick tape, coated with gold and viewed with a JEOL JSM-5310, Japan. Samples were also coated with carbon about $200 \AA$ thick with a Denton vacuum evaporator and viewed with an INCA X-sight Model 6587, Oxford, England, Energy Dispersive Spectrometer (EDS) with an automated qualitative elemental analysis mode and X-rayed mapping. Operating voltage of JEM-5310 was $15 \mathrm{kV}$.

\subsection{Soil column leached with simulated acid rains}

In order to simulate the long-term condition of the Guandu soils leached by acid deposition, and assess the influence of acidity on retention of $\mathrm{As}$ and $\mathrm{Pb}$, soil column samples were artificially leached with simulated acid rain. The Taiwan Environment Protection Agency (Taiwan-EPA) [8] reported that the acid rain $\mathrm{pH}$ range from 4.51 (winter) to 5.14 (summer) nearby Taipei City, 2004-2007. Mean annual precipitation, $\mathrm{SO}_{4}{ }^{2-}$ and $\mathrm{NO}_{3}{ }^{-}$concentrations are around $2486 \mathrm{~mm}, 58$ and $32 \mu \mathrm{eq} \mathrm{L}{ }^{-1}$, respectively. In order to enhance the effect of acid rains leaching experiments thus, we selected pHs 2 and 4 of simulated acid rains of 7450 and $45 \mu \mathrm{eq} \mathrm{L} \mathrm{L}^{-1}$ (i.e., $\mathrm{SO}_{4}{ }^{2-}$ concentrations) of sulfuric acid solu- 


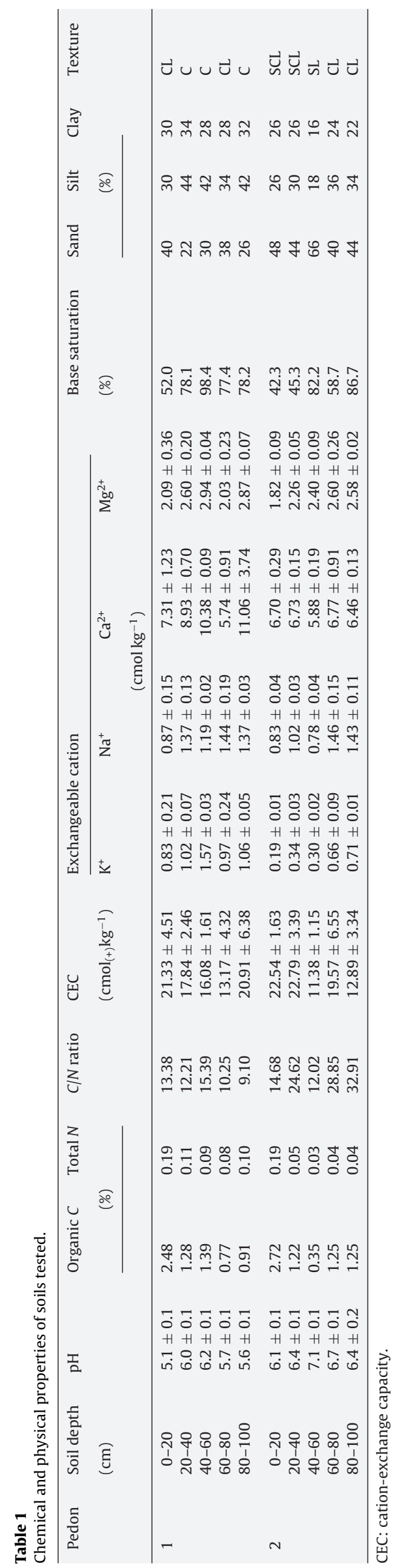

tions for the soil column leaching experiments. The $\mathrm{pH}$ of acid rains was monitored by pH-stat (TIM865 Titration Manager, Radiometer Analytic) and adjusted $\mathrm{pH}$ with $\mathrm{H}_{2} \mathrm{SO}_{4}$ or $\mathrm{NaOH}$ solution.

Acrylic columns of soil $10 \mathrm{~cm}$ long (internal diameter of $2.54 \mathrm{~cm}$, soil particle size less than $2 \mathrm{~mm}$ ) were collected from 0 to $20 \mathrm{~cm}$ (about $32.5 \mathrm{~g}$ weight of soils packed as surface soil horizon) and $20-40 \mathrm{~cm}$ (about $32.5 \mathrm{~g}$ weight of soil packed as subsoil horizon), placed into each $5 \mathrm{~cm}$ of soil column, and then simulated acid rain solutions was introduced. The bulk density of soils in a column was $1.30 \mathrm{~g} \mathrm{~cm}^{-3}$. The flow rate was adjusted with a mechanical vacuum extractor. Flow velocity observed from average saturated hydraulic conductivity of soils was $1.0 \mathrm{~cm} \mathrm{~h}^{-1}$. Pore volume of solution was calculated from saturated water hydraulic conductivity, porosity and total volume of soils in column. The detailed procedure was described by King et al. [18] and Liu et al. [19]. Percolate solutions were collected and analyzed for $\mathrm{As}$ and $\mathrm{Pb}$ concentrations. The break-through curve (BTC) was expressed as the relative concentration $(\mathrm{C} / \mathrm{Co})$ and pore volume number $(\mathrm{V} / \mathrm{Vo})$, where $\mathrm{Co}$ is the initial concentration added and $\mathrm{Vo}$ is the pore volumes of soil column.

\subsection{Sequential fractionations of soil $A s$ and $\mathrm{Pb}$}

Bulk soil samples were air-dried and with sequential fractionation for their As and $\mathrm{Pb}$ components, using the modified method of Wenzel et al. [20] or Yolcubal and Akyol [21]. One gram of oven-dried soil sample $(<2 \mathrm{~mm})$ was mixed with $25 \mathrm{~mL}$ of extracted solution. The soil samples were fractionated by the following sequential extractions: (1) with $50 \mathrm{mM}\left[\left(\mathrm{NH}_{4}\right)_{2} \mathrm{SO}_{4}\right]$ solution, at $20^{\circ} \mathrm{C}$ shaken for $4 \mathrm{~h}$ with continuous agitation (nonspecific bound easily exchangeable). (2) The residue from (1), continuous agitation with $50 \mathrm{mM}\left[\left(\mathrm{NH}_{4}\right)_{2} \mathrm{H}_{2} \mathrm{PO}_{4}\right]$ solution at $20^{\circ} \mathrm{C}$ for $16 \mathrm{~h}$ (strongly bound inner-sphere complexes). (3) The residue from (2) was extracted with $1 \mathrm{M}, \mathrm{pH} 5$ of NaOAc/HOAc buffer solution shaking at $20^{\circ} \mathrm{C}$ for $6 \mathrm{~h}$ (bound to carbonate). (4) The residue from (3) was

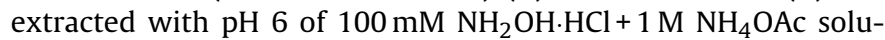
tion shaking $30 \mathrm{~min}$ (bound to $\mathrm{Mn}$ oxyhydroxides). (5) The residue from (4) was extracted with $\mathrm{pH} 3.25,200 \mathrm{mM}^{\circ} \mathrm{NH}_{4}$-oxalate buffer solution shaking $4 \mathrm{~h}$ in the dark at $20^{\circ} \mathrm{C}$, wash step with $\mathrm{pH} 3.25$, $200 \mathrm{mM} \mathrm{NH}_{4}$-oxalate buffer solution, shaking at $20^{\circ} \mathrm{C}$ for $10 \mathrm{~min}$ (bound to amorphous $\mathrm{Fe}$ and $\mathrm{Al}$ oxyhydroxides). (6) The residue from (5) was extracted with $15 \mathrm{~mL}, 30 \% \mathrm{H}_{2} \mathrm{O}_{2}$ and $3 \mathrm{~mL}, 20 \mathrm{mM}$ $\mathrm{HNO}_{3}$ at $85^{\circ} \mathrm{C}$ shaking for $2 \mathrm{~h}$, and $5 \mathrm{~mL}, 3.2 \mathrm{M} \mathrm{NaOAc}$ solution, shaking at $85^{\circ} \mathrm{C}$ for $3 \mathrm{~h} \mathrm{[22]} \mathrm{(bound} \mathrm{to} \mathrm{sulfides} \mathrm{and} \mathrm{organic} \mathrm{matter).} \mathrm{One}$ gram of each sample was digested with aqua regia solution for total chemical analysis [23]. The residual fractions were calculated from total As subtracted from $(1)+(2)+(3)+(4)+(5)+(6)$.

\section{Results and discussion}

\subsection{Soil physical and chemical properties}

Mean soil pH range was from 5.1 to 7.1. The range of CEC was from 11.38 to $22.54 \mathrm{cmol}_{(+)} \mathrm{kg}^{-1}$. Exchangeable $\mathrm{K}^{+}, \mathrm{Na}^{+}, \mathrm{Ca}^{2+}, \mathrm{Mg}^{2+}$ concentrations and base saturation are in the range from 0.19 to $1.57,0.78$ to $1.46,5.74$ to $11.06,1.82$ to $2.94 \mathrm{cmol} \mathrm{kg}^{-1}$, and 42.3 to $98.4 \%$, respectively (Table 1 ). These study pedons were close to the Chilung watershed with high groundwater tables, containing high exchangeable cations. Soil textures were clay, clay loam and silt clay loam. The soils can be classified as clay loam, mixed, thermic, Typic or Umbric Albaqualfs with respect to pedons 1 and 2 [24].

\subsection{X-ray diffraction, SEM images and EDS analyses}

The powder XRD pattern of beudantite collected from the bank of Huang Gang Creek showed 5.99, 5.72, 5.13, 3.67, 3.08, 2.97, 2.84, 

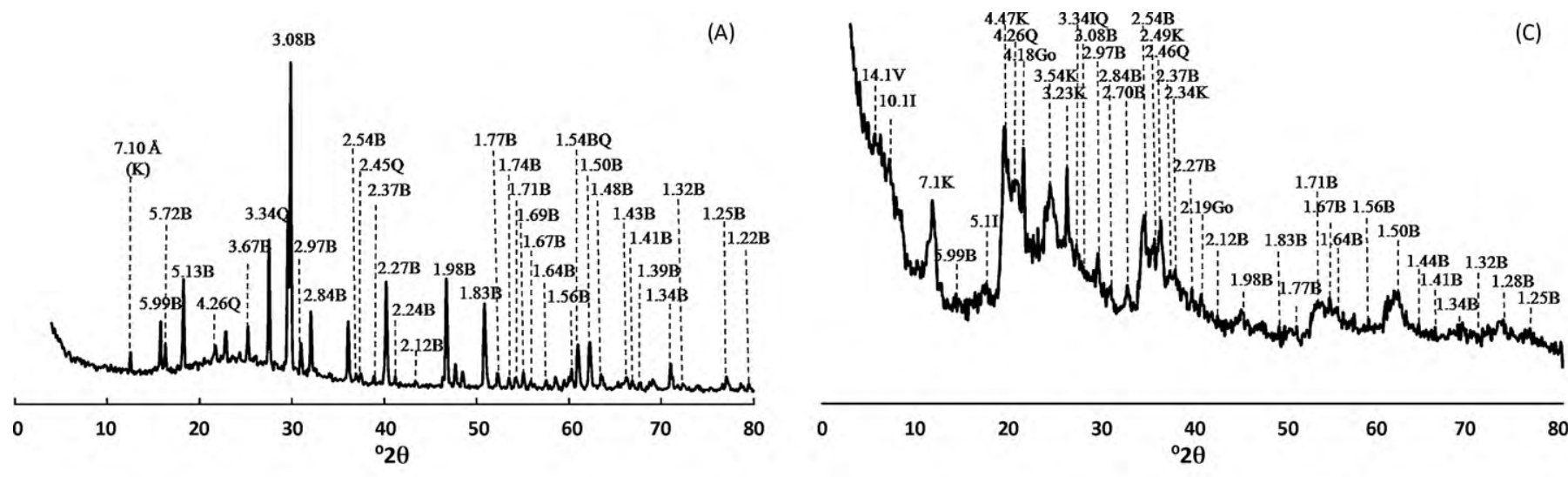

(B)
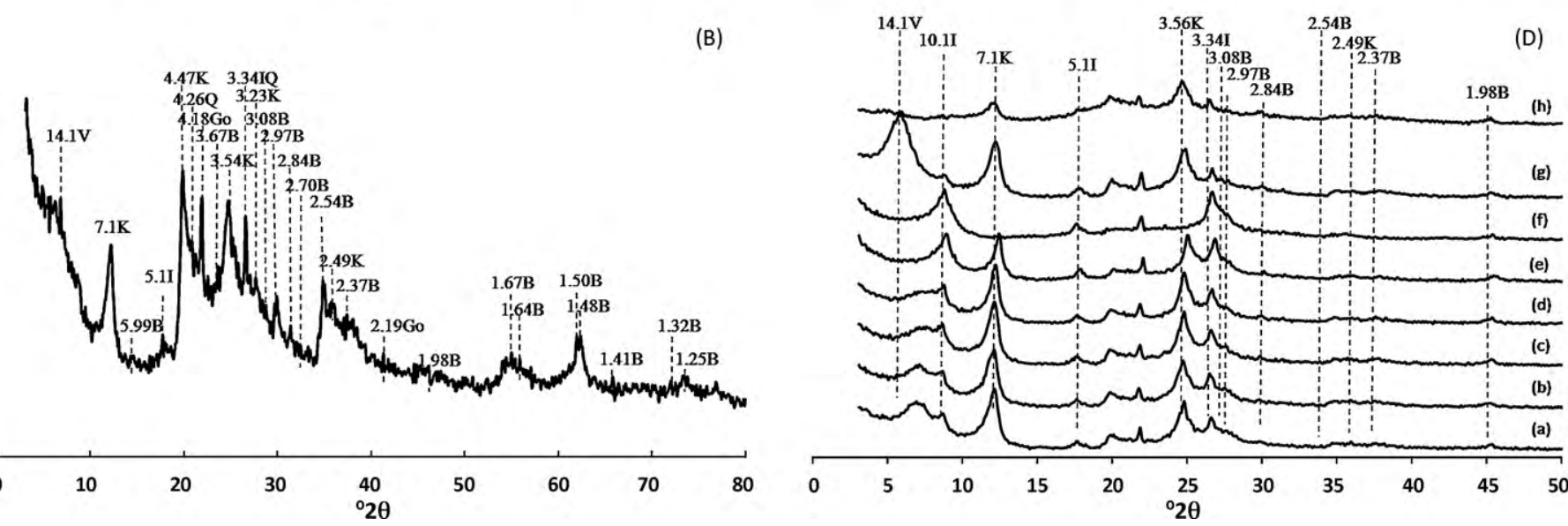

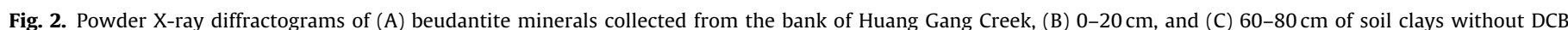

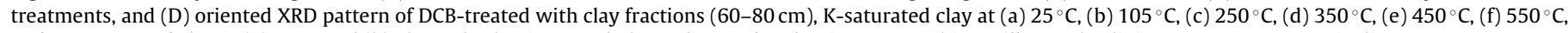
and Mg-saturated clay at (g) $25^{\circ} \mathrm{C}$ and (h) glycerol solvation. Symbols used are B: beudantite, Go: goethite, I: illite, K: kaolinite, Q: quartz, V: vermiculite.

2.54, 2.37, 2.27, 2.24, 2.12, 1.98, 1.83, 1.77, 1.74, 1.71, 1.69, 1.67, $1.64,1.56,1.54,1.50,1.48,1.43,1.41,1.39,1.34,1.32,1.25$ and $1.22 \AA$, which is consistent with JCPDS 19-689. This XRD pattern also exists the, 4.26, 3.34, 2.45, 1.82 and 1.54 Å of quartz (JCPDS 33 1161) (Fig. 2A) and a $7.1 \AA$ kaolinite peak. On the other hand, the powder XRD pattern of soil clay sample untreated with DCB (pedon 1, 0-20 cm), also shows 5.99, 3.67, 3.08, 2.97, 2.86, 2.54, 2.37, 1.98, $1.67,1.64,1.50,1.48,1.41,1.32$ and $1.28 \AA$ of beudantite; 4.18 and $2.19 \AA$ of goethite; 7.1, $4.47(020, h \mathrm{kl}), 2.49$ and 2.34 kaolinite; $4.26,3.34$ of quartz (Fig. 2B). The powder XRD pattern of soil clay fractions untreated with DCB (pedon 1, 60-80 cm) shows a similar diffractogram (Fig. 2C). This sample clearly showed the 10.1, 5.1 and $3.34 \AA$ of illite. X-ray powder diffractograms of the silt and sand fractions significantly show 3.08, 2.54, 2.54, 2.27, 2.12, 1.98, 1.83, $1.54,1.43,1.39,1.25,1.22 \AA$ of beudantite $d$-spacings, quartz and feldspar in the XRD reflection peaks.

The oriented XRD pattern of the DCB-treated clay samples (i.e., pedon $1,60-80 \mathrm{~cm}$ ), vermiculite was characterized by the $14.1 \AA$ at $\mathrm{Mg}$-saturated clay at $25^{\circ} \mathrm{C}$, collapsing to $10.1 \AA$ when K-saturated clay were heated at $110^{\circ} \mathrm{C}$. The $7.1 \AA$ of kaolinite at $25^{\circ} \mathrm{C}$ of the K-saturated clay, however, the $d(001)$ reflection peak was not observed after heating the K-saturated clay to $550^{\circ} \mathrm{C}$ (Fig. 2D). But $10.1 \AA$ Af illite XRD reflection peak with K-saturated clay was present when clay was heated from 110 to $550^{\circ} \mathrm{C}$. Semi-quantitative of clay minerals show the following trends: vermiculite $>$ kaolinite $>$ illite $>$ mixed layered clays in all pedons. After the clays were treated with DCB procedures to remove the free sesquioxides, clay fractions also showed significant criteria for beudantite XRD reflection peaks (i.e., 2.82, 2.97, 2.56, 2.37 and 1.98 still existing in the XRD pattern (Fig. 2D).
The above XRD analyses clearly show that beudantite exists in the soil profile of rice fields in the Guandu Plain. This confirms the story of irrigation waters being introduced from Huang Gang Creek to Guandu rice paddy soils during dry seasons, coming from Beitou Thermal Valley at that about 50-100 years ago (e.g., 1895-1945). Beudantite can assume a distinct morphology, which suggests it forms pseudomorphically feature (Fig. 3A). These XRD patterns, SEM and EDS (Fig. 3B) analyses provide further evidence that As and $\mathrm{Pb}$ (i.e., fine particle size of beudantite existing in water suspensions and soil clay fractions) remain in soil profiles. Beudantite formed in the most concentrated $\mathrm{As}$ and $\mathrm{Pb}$ system are composed of rather equidimensional particles and many of them are euhedral.

\subsection{Chemical analysis}

Mean $\mathrm{As}$ and $\mathrm{Pb}$ concentrations in bulk soil and clay fraction samples are shown in Table 2. This shows that this As concentrated in surface soils and $\mathrm{Pb}$ is concentrated at $60-80$ and $80-100 \mathrm{~cm}$, indicating the leaching of $\mathrm{Pb}$ to deeper soil horizons. However, arsenic movement in pedons is related to the fluctuation of underground water tables and soil redox potentials, $\mathrm{As}$ and $\mathrm{Pb}$ sorption capacities by soil particles, and distribution of beudantite particle sizes.

\subsection{Soil columns leached with simulated acid rains}

The mean BTC of soils with simulated acid rain leaching (pHs 2 and 4 ) is shown in Fig. 4A. After 22 pore volumes of leaching experiments (i.e., $\mathrm{pH} 4.0$ simulated acid rain) and 28 pore volume of $\mathrm{pH}$ 

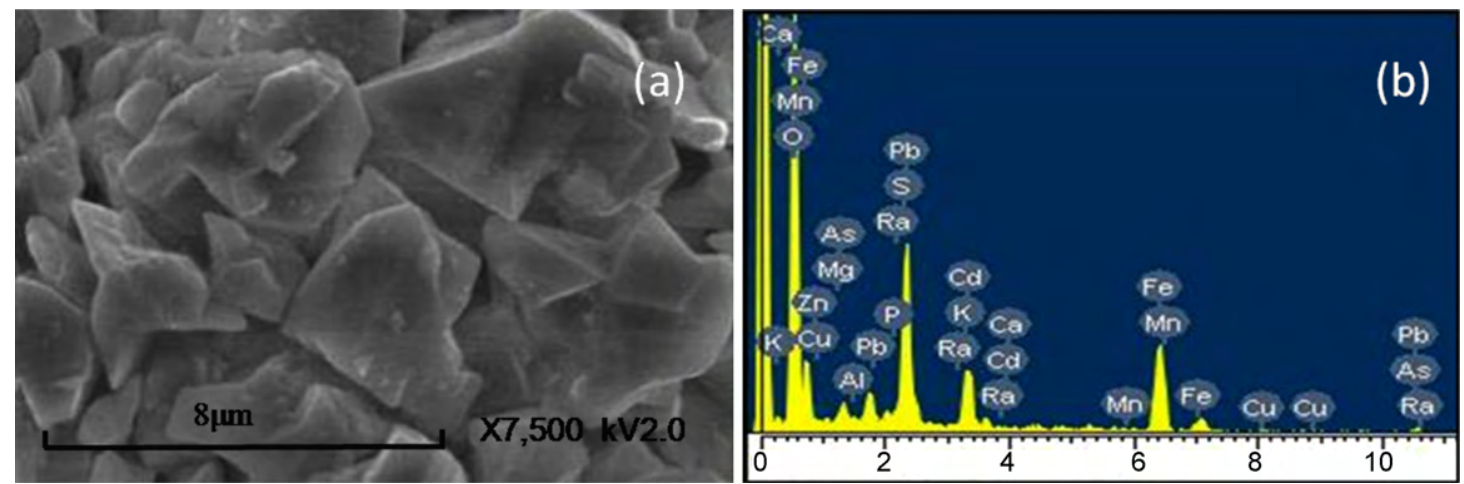

Fig. 3. (A) Scanning electron micrograph and (B) energy dispersive elemental analysis of beudantite.

2.0 simulated acid rain, the As concentrations in leachates reached the maximum. This is related to the dissociation constants of $\mathrm{As}(\mathrm{V})$ $\left[K_{1}=5.62 \times 10^{-2} ; \mathrm{p} K_{1}=2.2\right]$. Fig. $4 \mathrm{~B}$ shows the accumulation of As concentrations in leachates. Accumulation of As concentrations in

Table 2

As and $\mathrm{Pb}$ concentrations in bulk soils and clay fractions digested by aqua regia solution.

\begin{tabular}{lcll}
\hline Sample & Soil depth $(\mathrm{cm})$ & \multicolumn{2}{l}{ Element } \\
\cline { 3 - 4 } & & $\begin{array}{l}\text { As } \\
\left(\mathrm{mmol} \mathrm{kg}^{-1}\right)\end{array}$ & \\
\hline Bulk soil & $0-20$ & $3.88 \pm 0.05$ & $0.01 \pm 0.01$ \\
& $20-40$ & $3.31 \pm 0.32$ & $0.01 \pm 0.01$ \\
& $40-60$ & $3.61 \pm 0.43$ & $0.19 \pm 0.06$ \\
& $60-80$ & $2.66 \pm 0.08$ & $2.88 \pm 0.13$ \\
Clay fraction & $80-100$ & $1.96 \pm 0.12$ & $2.78 \pm 0.16$ \\
& $0-20$ & $3.15 \pm 0.08$ & $0.88 \pm 0.06$ \\
& $20-40$ & $2.81 \pm 0.02$ & $0.81 \pm 0.01$ \\
& $40-60$ & $2.17 \pm 0.14$ & $0.86 \pm 0.11$ \\
& $60-80$ & $2.83 \pm 0.01$ & $6.33 \pm 0.30$ \\
& $80-100$ & $1.56 \pm 0.49$ & $0.02 \pm 0.01$ \\
\hline
\end{tabular}
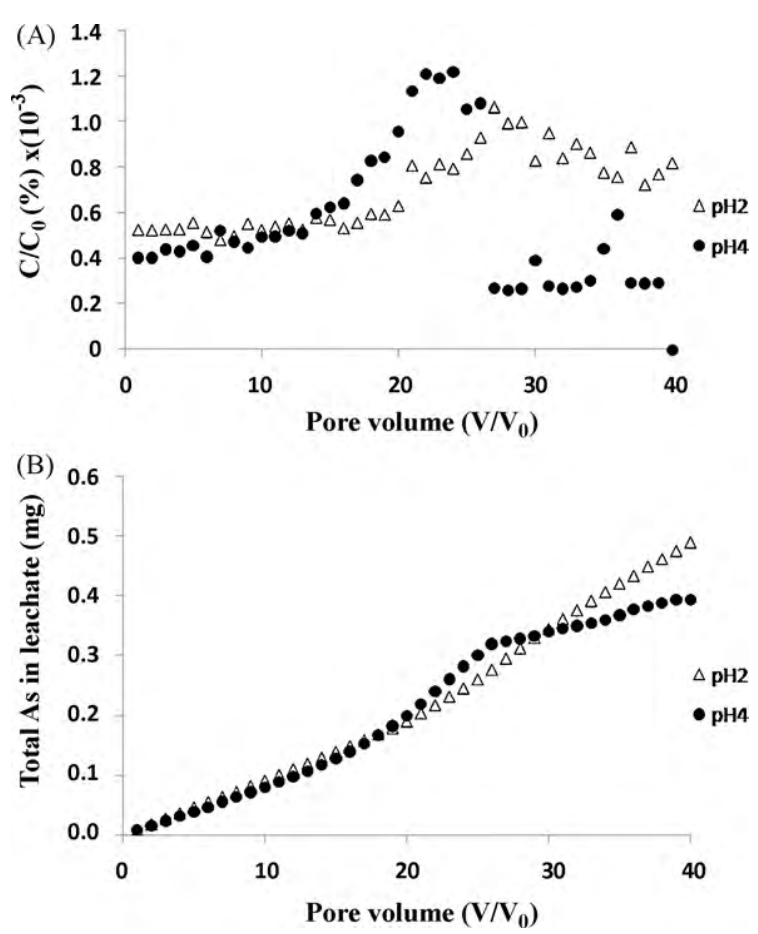

Fig. 4. Soil columns leached with simulated acid rains (A) break-through curve (BTC) of As, and (B) accumulated As after 40 pore volumes of leaching experiments. leachates were 0.489 and $0.394 \mathrm{mg}$ (i.e., total amounts of As in soil column is $17.51 \mathrm{mg}$ ), which correspond to 2.8 and $2.2 \%$ with respect to $\mathrm{pHs} 2$ and 4 of simulated acid rain leaching experiments after 40 pore volumes. This indicates that the soil beudantite is not be removed by simulated acid rains. Thus, beudantite cannot be completely leached out, even the Guandu Plain rice soils have passed through so many years of rice production, fertilization and precipitation. The mean As concentrations in grains, straws and roots of the Guandu rice field were $0.201(n=60), 4.36(n=28)$ and 244 $(n=28) \mathrm{mg}$ of $\mathrm{As} \mathrm{kg}^{-1}$, respectively (unpublished data). The arsenic concentration accumulated in the rice roots, whereas soil beudantite is still remaining in soil profiles. The remediation of As and $\mathrm{Pb}$ in the Guandu Plain merits further study.
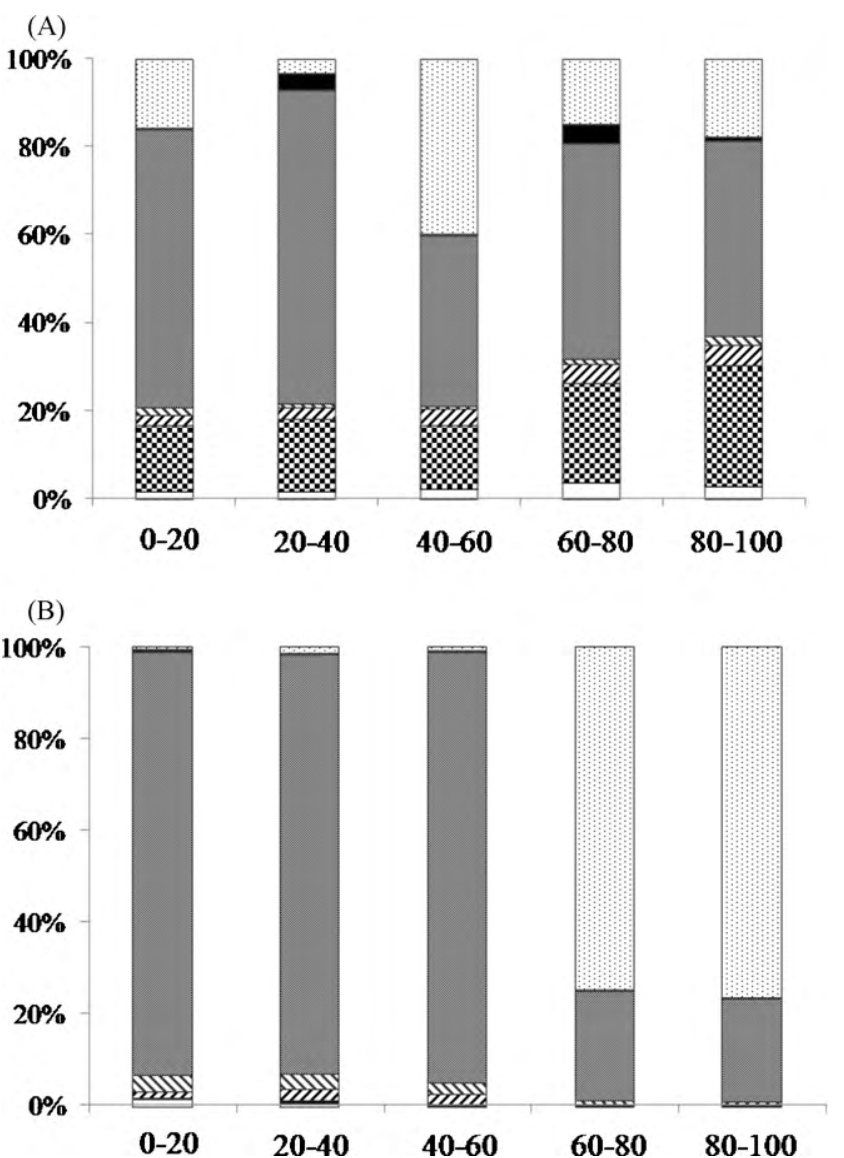

Fig. 5. As and $\mathrm{Pb}$ species in soil samples by sequential fractionations of $(\mathrm{A})$ As and (B) $\mathrm{Pb}$. 
The effect of calcium addition used as a stabilization agent was evaluated by arsenic desorption experiments from ferric water treatment residuals [25]. Arsenate desorption was induced in two ways: controlling solution $\mathrm{pH}$ in de-ionized water, and controlling solution $\mathrm{pH}$ in a phosphate solution where phosphate is a competing anion. Similarly, arsenic leaching decreased when field treatment residuals were treated with lime as stabilizing agent [26]. The use of humic acid for arsenic and heavy metal remediation may possibly be developed as an environmentally friendly and effective remedial option to reduce and avoid further contamination [27]. There are several reports, concerning lead and heavy metal removal by phosphatic clay [28], green algae Cladophora fascicularis [29]; phosphosilicate glass [30]; waste biomass of hazelnut and almond shells [31]; low cost adsorbents (i.e., activated carbon, kaolin, bentonite, blast furnace algae and fly ash) [32].

\subsection{Sequential extractions}

High percentages of As still remained in soil profiles as bound to amorphous, $\mathrm{Fe}$ and $\mathrm{Al}$ oxyhydroxides and residual portions by sequential fractionations, showing the following trend: bound to amorphous $\mathrm{Fe}$, and $\mathrm{Fe}$ and $\mathrm{Al}$ oxyhydroxides $>$ residues $>$ strongly bound inner-sphere complexes $>$ bound to carbonate $>$ bound to Mn oxyhydroxides $>$ bound to sulfides and organic matter $\approx$ nonspecifically bound, easily exchangeable fractions (Fig. 5A). On the other hand, Pb concentrations show a similar trend, except at $60-80$ and $80-100 \mathrm{~cm}$ soil horizon, whereas the $\mathrm{Pb}$ in residual fractions is higher than that bound to amorphous $\mathrm{Fe}, \mathrm{Fe}$ and $\mathrm{Al}$ oxyhydroxide fractions (Fig. 5B).

\section{Conclusions}

Chemical, physical, EDS and XRD analyses indicate that beudanite particles are present in the Guandu agricultural rice soils. The As and $\mathrm{Pb}$ contamination of rice soils was due to the careless use of irrigated waters introduced from the Huang Gang Creek of the Beitou Thermal Valley from 1895 to 1945 during drought seasons. The springs waters contain high concentrations of As and $\mathrm{Pb}$. Beudantite cannot completely leach out even though the Guandu Plain rice soils have passed through so many years of rice cultivation, fertilization and precipitation. Rice growth only uptakes low amounts of As. High concentrations of As and $\mathrm{Pb}$ still remained in soil profiles as bound to amorphous, Fe and $\mathrm{Al}$ oxyhydroxides and residual portions as shown by sequential fractionations. Thus, the remediation of As and $\mathrm{Pb}$ from the Guandu agricultural rice soils is an important research subject that merits further study.

\section{Acknowledgments}

The authors thank the National Science Council, Taiwan, The Republic of China, for financial support by NSC 88-2313-B002-279, 89-2313-B002-279, 90-2213-B002-279 and 92-2621-B-002-018.

\section{References}

[1] T.K. Chang, G.S. Shyu, Y.P. Lin, Geostatistical analysis of soil arsenic content in Taiwan, Environ. Sci. Health A: Toxic. Hazard. Subst. Environ. Eng. 34 (1999) 1485-1501.

[2] T.K. Chang, G.S. Shyu, W.L. Chang, W.D. Huang, J.H. Huang, J.S. Lin, S.C. Lin, Monitoring and investigation of heavy metal in soil of Taipei City. DEP-95-056, 2007 (in Chinese with English abstract).
[3] C.S. Ho, An Introduction to the Geology of Taiwan: Explanatory Text of the Geologic Map of Taiwan. Central Geological Survey, The Ministry of Economic Affairs, Taiwan, 1988, $192 \mathrm{pp}$.

[4] I.T. Wang, The characteristics and the concentration of toxic heavy metals and anions of hot springs in Taiwan. Master Thesis, National Yang Ming University, Taipei, Taiwan, 2005, 97 pp (in Chinese with English abstract).

[5] Y.J. Hsia, L.Y. Lin, Optimum water year selection for small forest watersheds, Taiwan Forestry Research Institute Bull. No. 353, 1981.

[6] Y.T. Lee, Radioisotope study of Hokutolite. Master Thesis, National Tsing Hua University, Hsingchu, Taiwan, 1961, 23 pp (in Chinese with English abstract).

[7] M.K. Wang, K.H. Houng, Y.W. Lin, K.K. Lim, J. Chin, Effect of pH, potassium, sulfate and iron concentrations on the formation of jarosite and goethite, Agri. Chem. Soc. 26 (1) (1988) 117-129.

[8] Taiwan Environment Protection Agency (Taiwan-EPA), Investigation and monitoring of deposition of acid rains, EPA-97-FA11-03-A045. Taipei, Taiwan, 2008 (in Chinese with English abstract).

[9] Soil Survey Staff, Soil Survey Manual, United States Department of Agriculture, Washington, DC, 1962, 503 pp.

[10] O.P. Mehra, M.L. Jackson, Iron oxides removed from soils and clay by dithionite-citrate system buffered with sodium bicarbonate, Clays Clay Miner. 7 (1960) 317-327.

[11] G.W. Gee, J.W. Bauder, in: A. Klute et al. (Eds.), Methods of Soil Analysis Part 1: Physical and Mineralogical Methods, Agronomy Monography, 2nd ed., vol. 9, Madison, WI, 1986, pp. 383-412.

[12] J.K. Rhoades, in: A.L Page et al. (Eds.), Methods of Soil Analysis. Part 2. Chemical and Microbiological Properties, Agronomy Monography, 2nd ed., vol. 9, Madison, WI, 1982, pp. 149-158.

[13] G. Blake, K.H. Hartge, in: A. Klute et al. (Eds.), Methods of Soil Analysis Part 1: Physical and Mineralogical Methods, Agronomy Monography, vol. 9, 2nd ed., Madison, WI, 1986, pp. 323-336.

[14] M.L. Jackson, Soil Chemical Analysis. Advanced Course, 2nd ed., University of Wisconsin, Madison, WI, 1979.

[15] C.B. Coffman, D.S. Fanning, Vermiculite determination on whole soils by cationexchange capacity method, Clays Clay Miner. 22 (1974) 271-283.

[16] C.W. Pai, M.K. Wang, W.M. Wang, K.H. Houng, Smectites in iron-rich calcareous soil, and black soils of Taiwan, Clays Clay Miner. 47 (1999) 389-398.

[17] G.W. Brindley, in: G.W. Brindley, G. Brown (Eds.), Crystal Structures of Clay Minerals and their X-ray Identification, Mineralogical Society Monograph, vol. 5, Mineralogical Society, London, 1980, pp. 411-438.

[18] H.B. King, M.K. Wang, S.Y. Zhuang, J.-L. Hwong, C.P. Liu, M.J. Kang, Sorption of sulfate and retention of cations in forest soils of Lien-Hua-Chi watershed in central Taiwan, Geoderma 131 (2006) 143-153.

[19] C.L. Liu, T.W. Chang, M.K. Wang, C.H. Huang, Transport of cadmium, nickel and zinc in Taoyuan red soil using one-dimensional convective-dispersive model, Geoderma 131 (2006) 181-189.

[20] W.W. Wenzel, N. Kirchbaumer, T. Prohaska, G. Stingeder, E. Lombi, D.C. Adriano Arsenic fractionation in soil using an improved sequential extraction procedure, Anal. Chim. Acta 436 (2001) 309-323.

[21] I. Yolcubal, N.H. Akyol, Adsorption and transport of arsenate in carbonate-rich soils: coupled effects of nonlinear and rate-limited sorption, Chemosphere 73 (2008) 1300-1307.

[22] A. Tessier, P.G.C. Campbell, M. Bisson, Sequential extraction procedure for the speciation of particulate trace metals, Anal. Chem. 51 (7) (1979) 844-851.

[23] US Environmental Protection Agency, Microwave Assisted Acid Digestion of Sediments, Sludges, Soils and Oils. Method 3051 A, US Environmental Protection Agency, Washington, DC, 2007.

[24] Soil Survey Staff, Keys to Soil Taxonomy, 10th ed., Washington, DC, United States Department of Agriculture and Natural Resources Conservation Service, 2006.

[25] J. Kumpiene, D. Ragnaldsson, L. Lövgren, S. Tesfalidet, B. Gustavsson, A Lättström, P. Leffler, C. Maurice, Impact of water saturation level on arsenic and metal mobility in the Fe-amended soil, Chemosphere 74 (2009) 206-215.

[26] J. Camacho, H.Y. Wee, T.A. Kramer, R. Autenrieth, Arsenic stabilization on water treatment residuals by calcium addition, J. Hazard. Mater. 165 (2009) 599-603.

[27] S. Wang, C.N. Mulligan, Enhanced mobilization of arsenic and heavy metals from mine tailings by humic acid, Chemosphere 74 (2009) 274-279.

[28] S.P. Singh, L.Q. Ma, M.J. Hendry, Characterization of aqueous lead removal by phosphatic clay: equilibrium and kinetic studies, J. Hazard. Mater. B136 (2006) 654-662.

[29] L. Deng, Y.Y. Su, H. Su, X.T. Wang, X.B. Zhu, Sorption and desorption of lead (II) from wastewater by green algae Cladophora fascicularis, J. Hazard. Mater. 143 (2007) 220-225.

[30] C.Y. Kims, H.J. Kim, J.S. Nam, Removal of lead ions from solution by phosphosilicate glass, J. Hazard. Mater. 153 (2008) 173-178.

[31] E. Pehlivan, T. Altun, S. Cetin, M.I. Bhanger, Lead sorption by waste biomass of hazelnut and almond shell, J. Hazard. Mater. 167 (1-3) (2009) 1203-1208.

[32] P.C. Mishra, R.K. Patel, Removal of lead and zinc ions from water by low cost adsorbents, J. Hazard. Mater. 168 (2009) 319-325. 